\title{
Subculture Movements and the Multi-faceted Nature of Resistance: when Dissidence Starts by Wearing Green Socks
}

\author{
Milàn CZerny
}

In November 2018, the underground Russian rapper "Husky" was filmed climbing and rapping atop a car after one of his concerts was canceled without explanation. "Husky" was sentenced to 12 days in jail for hooliganism. ${ }^{1}$ This video was widely shared on social media by dissidents opposing the "culture war" waged by the Kremlin. Vladimir Putin's regime restricts what constitutes "acceptable entertainment" in Russia. The rapper became a symbol of opposition to censorship: a concert in his support was staged and leaders of the opposition such as Alexei Navalny attended.

This event highlights how an artist can cross a thin line: cultural productions from sub-culture groups can turn into a form of resistance against an authoritarian regime. We tend to define dissidence in authoritarian regimes by marking a clear-cut Manichean division between the authorities and protesters. However, an analysis of subculture and underground movements, defined as alternatives to dominant cultural patterns set forward by authorities, highlights the multidimensionality of resistance. For Alexei Yurchak, subculture groups are not necessarily opposing authoritarian regime, but they can perform "parallel" practices to the ones promoted by authoritarian States, through music, style or dress. ${ }^{2}$ Their behaviors are within and outside of society at once, as their actions are in relation, one way

1. MacFarQuhar, 2018.

2. YURCHAK, 2013. 
SLOVO

or another, with the officially-promoted cultural patterns. Sub-cultures members revendicate alternatives ways of thinking to the hegemonic cultural practices imposed by authorities. Subculture groups strive to create spheres of freedom not necessarily directed frontally against authorities but not entirely controlled by it either. Still, an authoritarian regime is likely to aim at certain degrees of control over counter-culture movements as the latter seek greater freedom. Authorities shaping dominant culture form can appropriate themselves elements originally from subculture groups to enhance their legitimacy. As such, the relations between officially promoted cultural forms of expression and the manifestations of grass-root-driven culture are fluid and subject to continuous process of negotiation.

Three successive counterculture movements have emerged in Russia since the "Thaw, a period marking the birth of the first significant youth informal social movement: the "stilyagi" [hipsters] of the 1950s, the rockers of the 1980s and the punks in the 2010s. Three films produced in these last ten years have addressed these three successive underground musical movements: Valery Todorovsky's, 2008, musical film Stilyagi [The Hipsters], Kirill Serebrenikov's, 2018, Leto [Summer] and the documentary Pussy Riot: A Punk Prayer released in 2013. The three films represent successive generations of young people united in their will to "be different," to distinguish themselves from the mass and express creativity through music, clothes, argot, ritual. They reflect the existence of a spectrum of resistance and the various forms dissidence can take, from styles to direct actions aimed at social changes. As such, an analysis of Stilyagi, Leto and Pussy Riot: A Punk Prayer will permit to investigate the ways creativity can become a political statement.

We must however underline the noticeable difference between Stilyagi and Leto, which are fictional productions, and Pussy Riot: A Punk Prayer a documentary which recount the trial that sentenced three members of the Pussy Riot band to two years in a penal colony. A clear distinction must be kept in mind between the lived sufferings of the punk Pussy Riots activists and the mere representation of the persecutions of rockers and hipsters. However, this article argues that these three productions resonates in comparable ways in current-day Russia. The political climate under the leadership of Vladimir Putin led Todorovsky and Serebrenikov to reflect on Soviet sub-culture groups in their films while, at the same time, the Pussy Riots were opposing in the reality the Kremlin's cultural policy. This cultural policy, which is defined by David Throsby as "the promotion or prohibition of cultural practices or values by governments, corporations, other institutions and individuals" to reinforce the legitimacy of rulers, stands in opposition to sub-culture 
movements. ${ }^{3}$ Hence, the three productions can be put in a dialogue to further our understanding of the meanings and values of counter-culture movements in an authoritarian state.

This article will ask how cinema can permit to shed light on the perpetual renegotiation between a dominant culture, imposed by an authoritarian regime, and a sub-culture, originating from grass-roots movements, which can be tolerated or repressed? I will argue that these three films advocate for greater freedom through the representation of sub-culture movements and underline the multi-faceted nature of resistance. After a short presentation of the three productions, I will highlight the creativity of the three subcultures movements and the ways they are represented in the films. Subculture groups cultivate their differences from the imposed cultural forms of authorities. It leads them to reflect on the dominant culture and develop creative behaviors. I will then move on to analyze the struggle over history taking place in Stilyagi, Leto and Punk Prayer. The productions echo current issues in Russia and reflect upon various epochs from a contemporary point of view. They underline the intemporal need for freedom and advocate emancipation from cultural patterns controlled by authorities within an historical context. Finally, I will turn to the relations of the young musicians to the authorities to underline the shifting boundaries of what is deemed as tolerable by the government.

\section{Presentation}

Set in 1955, after the death of Stalin but before Krushchev's secret speech, Stilyagi reflects upon the first notable subculture movement that emerged in USSR. It depicts "stilyagi," young hipsters from the Soviet elite, exposed to western music, style and dance, trying to express themselves in a society composed of "squares," homogenized citizens forming a gray masse. The minimal plot focuses on Mels, a young boy named after Marx, Engels, Lenin, Stalin, making his way from a communal apartment inhabited by the proletariat to the world of the stilyagi. The technicolor palate of the film permits to mark a clear-cut binary division between the Soviets, following the inhibiting officially promoted way of life, and the stilyagi wearing bright color clothes. It is a light-hearted musical which reads at first as a farce, destined for a mass audience and devoid of all critical weight. The film acquired a cult status in Russia and was supported by state-controlled television channels, PervyiKanal and Rossiza.

3. Throsby, 2010, p. 8. 
SLOVO

294 Les Voyages lointains des écrivains polonais $\left(\mathrm{XX}^{\mathrm{e}}-\mathrm{XXI}^{\mathrm{e}}\right.$ siècles $)-\mathrm{n}^{\circ} 51$

However, an analysis that goes beyond the Disney-like songs and non-diegetic cartoon captions permit to uncover a genuine countercultural movement, striving for greater liberty. The director of Stilyagi, Valery Todorovsky draw parallels between the stilyagi of the 1950s and the Soviet rock of groups of the 1980s by incorporating songs from the Perestroika period. In fact, there are great similarities between Stilyagi and Leto, a film released in 2018 focusing on the early career of Viktor Tsoi, the rock legend of the 1980s, and his band "Kino." Rock played a significant role in the youth counterculture of the early 1980s, a period marked by the emergence of antiestablishment discourses, conveyed notably through music. In the 1980s, Viktor Tsoi, the protagonist of Leto, called for radical political changes and became the leader of youth dissidence for creating the "anthem" of the Perestroika: "My zhdem peremen" (We are waiting for changes"). ${ }^{4}$

Leto is a musical in black and white punctuated by occasional hot burst of colorful handwritten drawings. It is a graceful, poetic film celebrating the energy of youths in a period where freedom seemed attainable. The representation of this hope in emancipation clashes with the context of production of Leto, giving to the film its deeper significance. Kirill Serebrenikov, the film director, was detained in house-arrest for more than a year on fraud charges, a sentence that many Russian actors denounced as political motivated. As such, the film had a very restricted distribution in Russia, despite winning an award at the Cannes Film Festival in $2018 .^{5}$

The documentary Pussy Riot- A Punk Prayer released in 2013 also faced censorship in Russia. It was destined to western audience and received a special award at the 2013 Sundance Festival for its "punk spirit." ${ }^{3}$ As for Leto and Stilyagi, the will to advocate for greater freedom through music is at the center of the Pussy Riot feminist punk band. The Russian-British documentary Pussy Riot- A Punk Prayer follows three activists of the Pussy Riot group, judged after they erupted singing and wearing bright color balaclavas into "Moscow's Cathedral of Christ the Savior" to denounce the links between Putin and the Orthodox Church. As such, despite differences in the public targeted, mass Russian audiences for Styliagi, and western intellectual spheres for Leto and Pussy Riot: A Punk Prayer, the three productions are united in their will to underline the value of freedom.

4. KagANOVSKY, 2014.

5. WiLkinson, May 11, 2018.

6. The Hollywood Reporter, $26^{\text {th }}$ January, 2013. 


\section{The creativity of subculture groups}

The three films display members of subculture groups, characterized by their desire for creativity, non-conformity, their will to challenge dominant cultural norms and propose alternative scheme to ones imposed by authorities. Creativity is a mark of freedom, as stated by Leto's scriptwriter in an interview for Current Time, the Russian-language network affiliated to Radio Free Europe: "our film is about the spirit of creative freedom in condition of repression." 7 This is not to say that the various creative patterns deployed by subculture groups are all equally directly opposing the authorities. They create a spectrum of resistance, some of their behaviors consist in more confrontational approach to cultural patterns promoted by the authorities while some elements originating in subculture groups can be tolerated.

Sociologists of the Centre for Contemporary Cultural Studies (CCCS) identified style as a significant component of sub- and counter-culture expressions. ${ }^{8}$ They determined four dimensions of counter-cultural movements: style, dress, music, ritual, and argot. Together these elements generate a great deal of creativity that we can find in the three films. Hipsters of Styliagi, rockers in Leto and the Pussy Riots are characterized by their creativity, first of all as musicians, but equally in their behaviors and will to create new norms.

The stilyagis are recognizable by their bright clothes and their hair-style, they listen to jazz and rock, they dance the "boogie-woogie" and they renamed their meeting-point as "Broadway," a meaningful geographical renaming at the time of the Cold War. Similarly, rockers in Leto stand out of the crowd by wearing jean jackets and sunglasses. Members of the bands have long hair, marking their opposition to young soldiers required to have shorter hair as they were sent to Afghanistan for the war in the eighties, as displayed in the film. Leto and Stilyagi highlight that counter-cultural movements engage in various activities to differentiate themselves from cultural norms imposed by authorities.

Similarly, in real-life, Pussy Riots also make sure to be noticed and distinguished from the masses by wearing fluo balaclavas and tights when they play loud punk-rock. The feminist activists explained their look during trial: the bright colors of their clothes are a way to distance themselves from criminals often portrayed wearing dark balaclavas. They wish to bring joy, be identifiable around the world and create a political satire of the regime as their clothes are entertaining.

7. Davletgildeev, April 19, 2018.

8. Williams, 2007. 
SLOVO

296 Les Voyages lointains des écrivains polonais $\left(\mathrm{Xx}^{\mathrm{e}}-\mathrm{XXI}^{\mathrm{e}}\right.$ siècles $)-\mathrm{n}^{\circ} 51$

There is a creative reflection behind their style, the choice of their apparel. Their "inappropriate clothing" was mentioned during the trial as an additional charge against the activists, proving that adopting creative styles different from the rest of the population can represent a form of resistance to authoritarianism.

The creativity of the stilyagis and rockers may seem to be merely an imitation of Western cultural patterns. They employ English words and are attracted by American culture, but they do not merely copy their western counterparts. For instance, Stilyagi displays "a true Soviet invention" brought about by "a combination of a lack of raw materials and pure ingenuity:" western records were copied on X-ray plates by stilyagis. ${ }^{9}$ This "independent technology" conferred to these homemade records their name: rock on bones. ${ }^{10}$ Similarly, Soviet rockers in Leto are influenced by western rockers such as David Bowie or T-Rex but they reinterpret songs by translating lyrics. Rockers must play with words and adapt western songs to make sense of them in the Soviet environment. This is an overly creative exercise which creates bridges between the Western and the Eastern bloc. It consists of a resistance to the framework of the Cold War, opposing two sides, as exemplified by Reagan's speech pronounced in 1983 to denounce the USSR as an "evil empire." 11

The last form of freedom represented is related to the very bodies of the subculture group members. Stilyagis, rockers in Leto and the Pussy Riots are characterized by their sexual freedom: they challenge sexual Soviet social norms. One stilyagi is openly gay, the hipsters multiply lovers and they have sexual relations before getting married. Similarly, in Leto, young people dance naked around the fire, stripping of clothes and norms to advocate greater freedom. Mike Naumenko, a Soviet rock star, tolerates that the musician he is mentoring, Viktor Tsoi, sleeps with his wife. Pussy Riots advocate feminist and LGBTQ rights, in opposition to the Russian legislation restricting "propaganda of nontraditional sexual relations." 12

As such, "nontraditional" sexual behaviors and oppositional art can be strong weapons in the hands of subculture groups, manifesting their desire for freedom through creation and deconstruction of societal norms. The three generations of sub-cultures members take aim at the monolithic tendency of the Soviet society. Todorovsky explained why he portrayed the generation of the styliagi in his film: "they walk against everyone and in green socks" to oppose those who "merge into

9. KaganovsKy, 2014.

10. YURCHAK, 2013.

11. REAGAN, 1983.

12. Moscow Times, March 30, 2018. 
one mass," "all sorts of $\mathrm{Nash}^{13}$ and the like." ${ }^{14}$ As such, through Stilyagi, Todorovsky expressed his opposition to nationalist groups seeking to homogenize society. Resistance to authoritarian control on norms, behaviors, style and sexual practices can take diverse forms confronting the regime at various degrees: wearing "green socks," hairstyle, having homosexual relations or wearing fluo balaclavas.

\section{Nostalgia as a tool of freedom}

Stilyagi and Leto received mixed reviews in the Russian press. Criticisms were not directly aimed at the representation of "deviant" behaviors but rather questioned the historical accuracy of the films. This highlight the conflict over historical memories of the USSR in modern-day Russia as Vladimir Putin "reinvented historic narratives of the Soviet period to advance the notion of Russia's enduring greatness and foster a sense of patriotism." ${ }^{15}$ The creation of myths around the Soviet period in contemporary Russia take place through the promotion of certain cultural practices, exemplified by the reinstation of the Soviet national anthem under Putin's first term, at the expense of others. Stiliyagi and Leto, by representating of Soviet subculture groups and by stressing the repressions conducted by Soviet authorities, promote freedom in their construction of alternatives to the Kremlin's rewriting of history.

The local newspaper of the Stavropol region, Stavropolskaya Pravda, denounced the "excessively ideological" representation of the 1950s in Stilyagi as "the authors of the film were at that time, of course, not yet born." ${ }^{16}$ The author of this article does not "remember the people in the dark-brown clothes as they are shown in the film" and points out to the perfumes and sundresses worn by her mother. Similarly, Lady.mail.ru, a Russian tabloid, questioned readers: "Were the 50s like in Stilyagi ?" ${ }^{17}$ In Leto's case, Boris Grebenshchikov, a rocker of the 1980s in the USSR, denounced, in an interview for the largest Russian news agency "Tass," the "pure lie from the beginning to the end" that constitute the film which "make everything hundred times worse than it really was" as rockers "were

13. Nashi was a political youth movement supported by the Kremlin. See Mijnssen, 2014. 14. KaganovsKy, 2014.

15. Nikolayenko, 2008.

16. LARIONOVA, 23 January 2009.

17. KorzINA, $4^{\text {th }}$ February 2009 
SLOVO

298 Les Voyages lointains des écrivains polonais $\left(\mathrm{XX}^{\mathrm{e}}-\mathrm{XXI}^{\mathrm{e}}\right.$ siècles $)-\mathrm{n}^{\circ} 51$

free." ${ }^{18}$ Russian mainstream newspapers insisted on the historical inaccuracy of these films.

However, Stiyiagi and Leto do not claim to provide a genuine representation of Soviet era. They seek to demonstrate the intemporality of freedom. Serebrenikov and Todorovsky employed the past as a mean to depict the timeless quest for liberty. As such, the issues treated in the films resonate in contemporary's Russia and expose the productions to criticisms in media as the productions create a certain memory of the Soviet past that diverge from the Kremlin's political use of history. ${ }^{19}$

Stilyagi incorporates elements from various time periods to underline the intemporal value of creative freedom in conditions of repression and the continuous relevance of subculture movements. The music of the film is not from the 1950s but from the Perestroika period. In Stilyagi, many bands represented in Leto, such as "Kino" and "Zoopark" are credited with songs. Todorovsky explains his choice of incorporating Perestroika's artists by pointing that the "people who created Russian rock" "were the children of stilyagis." ${ }^{20} \mathrm{He}$ indicated that his "film is not about a particular era of group but about the very possibility of dissent, of not going along with the gray masses" and the need to cultivate difference and noncompliance. ${ }^{21}$

The last scene of Stilyagi represents $a$ "march of the non-conformists" 22 : subculture groups from various time periods such as punks, goths, reggae-men joyfully stroll down contemporary Moscow's Gorky Street. An overhead crane shot is employed in the closing musical number to include in the frame the vast number of people marching to revendicate their differences and defend the possibility of independent thought. The Pussy Riots would not be out of place in this "parade" of subculture groups. Bridges are created between various subculture movements to construct a community of non-conformists, in opposition to Russian authorities' promotion of patriotism to unite the population for political goals. Indeed, Kiril Serebrenikov, in his own words, "brings life to a culture that is not acceptable for the authorities according to the cultural norms set by the government, exactly like Leningrad in the 1980s was not the right time and right place to play rock music." ${ }^{23} \mathrm{He}$ uses the past to underline the constant relevance of subculture groups opposing authorities.

18. Belikov, 7 June 2018.

19. LiÑ̃́n, 2010.

20. KaGANOVSKY, 2014.

21. Ibid.

22. Ibid.

23. MACHERET, 2018. 
Stilyagi and Leto are imbued with nostalgia. The past is used as a breeding ground for future freedom. For Svetlana Boym, the past is a two-edged sword; the government can employ in order to legitimize its rule, but it can also be conceived as a subculture practice in the hands of citizens, using it to oppose the historical narratives set by the authorities. ${ }^{24}$ She usefully distinguishes two types of nostalgia: restorative and reflective nostalgia. Restorative nostalgia is used by authoritarian governments to vehiculate ideas concerning "national revival," "traditions" and restore a "greatness of the past." ${ }^{25}$ For instance, this is exemplified in Putin's Russia through the resurgence of the celebrations of the "Great Patriotic War" and legitimization of the Molotov-Ribbentrop Pact. Films praising the efforts of Soviet forces in WWII have multiplied in Russia under Putin.

At the opposite, Boym defines "reflective nostalgia" as an "antidote against the dictatorship of nostalgia." ${ }^{26}$ Reflective nostalgia consists in reflecting on the past in a constructive manner to open alternatives to the historical narratives created by the State. Boym defines this use of the past as a countercultural practice since it permits to reflect and oppose the official narratives set forward by the State. Citizens should not refrain from taking the past into their own hands as "the fantasies of the past determined by the needs of the present have a direct impact on the realities of the future." ${ }^{27}$ Reflective nostalgia permits to oppose narratives of the past shaped by the government, escape the present controlled by authorities and hence imagine different futures.

This underlines the role films such as Stilyagi and Leto can have. Both productions are meant to provoke a reaction in the viewers' minds: we are encouraged to interrogate ourselves about the reality of life in Soviet Union and compare it with the present days. The two directors make sure to bridge various epochs, as previously displayed. Stilyagi and Leto employ a reflective form of nostalgia: they advocate the need to "take responsibility of our past and not let others "prefabricate it for us," ${ }^{28}$ in Boym's words.

In Leto, through the use of a dreamy nostalgia-inducing black and white, Serebrenikov's poetic creation acts as a counternarrative to the homogenized rewriting of history under Putin. For Putin, the end of the Soviet Union was a period

24. Воум, 2008.

25. Ibid.

26. Ibid.

27.Ibid., p. 8.

28. Ibid., p. 18. 
SLOVO

300 Les Voyages lointains des écrivains polonais $\left(\mathrm{XX}^{\mathrm{e}}-\mathrm{XXI}^{\mathrm{e}}\right.$ siècles $)-\mathrm{n}^{\circ} 51$

of "genuine drama." ${ }^{29}$ At the opposite, by shedding light on the lives on Soviet rockers attracted by western music in the early 1980s, Serebrenikov highlights that the Perestroika was a period marked by hopes in a different future and new forms of expression. Nostalgia is fundamentally a counter-culture practice in authoritarian regime that tries to rewrite the past to make it fit into their imposed vision of the present. Leto and Stilyagy offer an opportunity to oppose the homogenized representation of history conveyed by Vladimir Putin's regime.

With Stilyagi and Leto, Serebrenikov and Todorovsky challenged the official representation of the Soviet era. The contemporary Russian State "has sought to turn the past into a powerful symbolic resource" and employed cultural memory to discredit the opposition through television and cinematic production. ${ }^{30}$ The Kremlin has emphasized the continuity between the Soviet past and Putin to stress that Russia has the legitimacy to be a "great power" and has been under a constant threat from domestic and foreign actors which, in turn, necessitate a strong and centralized State. ${ }^{31}$ Serebrenikov and Todorovsky, at the opposite, underline the positive influence of western culture on Soviet underground music and stress the emancipatory benefits of grassroots movements rather than top-down imposition of cultural patterns.

Consequently, the producers faced criticisms from the media, as the latter seek to impose a homogenizing narrative of the past and cultural practices that reflect a certain perspective of Soviet era. Similarly, the Pussy Riot members faced criticisms from newspapers that referred to historical memory to discredit the punk-activists. Journalists and television presenters equated the singing of the Pussy Riots in Moscow's Cathedral of Christ the Savior with the Bolsheviks' repression conducted against religious worshippers after the Russian Revolution. Orthodox worshippers compared the Pussy Riots' "blasphemous acts" to the transformation of the Cathedral in a pool during the USSR. The two events were equally denounced as violation to religious freedom. The history of the Orthodox Church in Russia during the Soviet era was used as an additional charge against the activists. To defend themselves, the feminist activists claimed that they were not aiming at religion per se but rather at the links between Putin and the authority of the Orthodox Church in Russia.

During the trial, the Pussy Riot trio also employed Soviet history, but from another perspective, to confront the instrumentalization of the Bolshevik past

29. Osborn, March 2, 2018.

30. WiJERMARs, 2018, p. 8.

31. Laruelle, 2009. 
by the authorities. The Pussy Riot members argued that "nothing changed since Soviet era" to point out that artists defying social norms are still prosecuted. Nadya Tolokonnikova, the Pussy Riot activist, compared herself in the documentary to artists oppressed under Stalin: "we are not defeated, just as Soviet dissidents were not defeated. They disappeared in psych wards and prisons, but they pronounced their verdict on the regime." The activists employed this comparison to reject the accusations that Pussy Riot was "persecuting" worshippers, as the Bolsheviks used to. The interpretation of the past was at the center of the trial as both sides used it to legitimize their positions. Pussy Riot, Serebrenikov and Todorovsky employ the past to counter the homogenizing narratives created by Putin's regime. History can be used by authorities claiming the need to reinstitute the greatness of the past, but cinema can reinterpret the past, reflect upon and highlight the constant need to cultivate differences as means to challenge the intolerance of nonconformity.

\section{The relations with the authorities}

The three sub-culture groups represented do not oppose authorities in a similar manner in the three films. It is necessary to distinguish various degrees of opposition from sub-culture groups. The relations of subculture groups with the authorities are complex as the boundaries of what is deemed as tolerable by the authorities are not clearly defined.

J. Patrick Williams in "The Multidimensionality of Resistance in Youth-Subcultural Studies" usefully distinguishes diverse types of subculture resistance, going from "hair styles and clothes to burning cars and smashing corporate windows." ${ }^{2} \mathrm{He}$ distinguishes "passive" and "symbolic" resistance, manifested through appearances, to more active forms of opposition directly seeking social changes. The styliagis represented in Todorovsky's film are rather an example of the first form of resistance while Pussy Riots are at the other end of the spectrum. The Pussy Riots directly organized their actions against symbols of authorities: a jail, the Red Square in Moscow or the Christ the Savior Cathedral representing the power of the Orthodox Church.

In Todorovsky's film, the stilyagi do not fight against the authority, they merely adopt different clothes from the rest of the population. When one of the stilyagi, Bob, is apprehended buying forbidden records this does not provoke revolutionary reactions within the subculture group. Similarly, rockers in Leto are not directly aiming at undermining the power of the authorities. Alexei Yurchak stressed the 
SLOVO

Les Voyages lointains des écrivains polonais $\left(\mathrm{XX}^{\mathrm{e}}-\mathrm{XXI}^{\mathrm{e}}\right.$ siècles $)-\mathrm{n}^{\circ} 51$

"lack of interest" rather than the resistance against power by late Soviet society rockers. ${ }^{33} \mathrm{He}$ defines these cultural patterns as "parallel" to form of cultures, not directly against authorities but neither totally under control.

The existence of this parallel sphere is clearly depicted in Leto: the rockers are in a train wagon when authorities begin to oppress them, the music starts and sets in motion a dream-like world incorporating handmade drawings. In this parallel world, rockers directly fight with the authorities. They embrace and kiss KGB officers, a direct reference to actions organized by members of the Pussy Riot band as the punk activists filmed themselves kissing policewomen in Moscow metro stations.

Furthermore, in Leto, Kirill Serebrenikov incorporated a character, "the Sceptic," whose very role is to distinguish the "real" world from a "parallel" one created by rock music. He raises a sign indicating that "none of this happened" to reintegrate rockers in the reality when music makes them shift away from the control of the authorities. The rockers had to demonstrate a certain degree of loyalty to authorities and not aim to dismantle power structures. ${ }^{34}$ They were, at once, inside and outside the Soviet system. Inside the system as they agree to certain of its rules and outside of it by their will to dissociate themselves from the dominant cultural forms.

This is equally the case in Stilyagi: despite adopting alternatives clothes, the "hipsters" are all, expect Mels, from elite families which allows them to have access to the Western world. Hipsters of Stiliagi must pay police forces to enter their clubs. At the beginning of Leto, the KGB closely manage and scrutinize spectators attending Mike Naumenko's concert. Authorities accept that the concert takes place, but under strict conditions. As such the relations between subculture groups and authorities are in continuous process of renegotiations.

This claim may seem to be undermined by the Pussy Riots' case as they adopted more confrontational actions to speak truth to power. They confronted the authority of the Orthodox Church and its ties with Vladimir Putin by staging a performance inside Moscow's Cathedral of Christ the Savior. They were sentenced to two years in penal colony for their acts. However, at once, authorities did not as severely punish Pussy Riots' previous actions. Putin sought to reinforce his authority at the time of the trial as mass protests were taking place in Russia. The President of the Russian Federation underlined his will to limit freedom of expression by stating, as represented in the documentary, that "it was unclear why they [the Pussy Riots] were not picked up for their earlier stunts."

33. YURCHAK, 2013.

34. Ibid. 
At once, Putin's Prime Minister Dmitri Medvedev "opposed" the court's decision to send the activists in jail. ${ }^{35}$ In the Pussy Riot's trial and as represented in the fictional productions, authoritarian regimes seek to limit freedom of expression whilst not appearing as an overly censoring regime. Pussy Riots are merely allowed to use their "freedom of expression and artistic creation" within a legal framework as absurdly stated by one of the prosecutors during the trial. Creation is fundamentally borderless and artistic creations frequently plays with legal frameworks. Putin's regime seeks to preserve its legitimacy in the eyes of Russian citizens by declaring that citizens can express themselves, but he does not fail to add that rules must be followed. These "rules" delineating between what can be said and what cannot be are voluntarily unclear and vaguely defined.

As such, the Pussy Riot trial is an exemplary case of the use of periodic crackdowns by a authoritarian regime to create a sense of permanent instability. In Putin's Russia, authorities create a constant climate of anxiety and fear by not clearly defining the limits of what is deemed as tolerable. This allows them to maintain their rule as citizens will tend to adopt self-censorship behaviors. They refrain themselves from voicing their opinion even if the authorities are either absent or irrelevant. Citizens incorporate the need to accept censorship and bend to power-holders to keep themselves safe. They fear they will cross a blurry line set by authorities to delineate what is tolerable from what is not.

The theme of constant instability and shifting boundaries of the tolerable is equally depicted in Stilyagi and Leto. The two films open on a similar scene. In the former, the "hipsters" are chased by Komsomol youth, an organization controlled by the Communist Party. In the latter the KGB is looking for rock fans in closets. It is displayed as a mere cat and mouse game between authorities and the young subculture groups. However, the control of the authorities is reinforced throughout Stilyagi with greater consequences for the hipsters. As stilyagis were not directly participating in actions prohibited by the laws, they are framed as "anti-patriotic" to legitimize punishing actions taken against them. This is exemplified in the reproduction in the film of an original frontpage of a newspaper from the mid-50s warning that "today they play jazz, tomorrow they sell the motherland." Consequently, at the end of the film, most stilyagi turn their back on their sub-culture identity: Polly, Mels' wife, become a Soviet housewife, Bob is sent to jail, Fred becomes a diplomat in the USA. Because of the publication of articles against them and the intensification of repression, stilyagi bend to the authorities' oppression and acquiesce to self-censorship. 
SLOVO

304 Les Voyages lointains des écrivains polonais $\left(\mathrm{Xx}^{\mathrm{e}}-\mathrm{XXI}^{\mathrm{e}}\right.$ siècles $)-\mathrm{n}^{\circ} 51$

At once, the end of the film ends on a positive note since Mels, the protagonist, leads a movement of joyful non-conformists. The director closes his film by advocating the need to oppose the tendency of citizens toward self-censorship in authoritarian regimes. Creative behaviors of subculture groups must be preserved as they set an example for the rest of the population, prone to refrain themselves from voicing their opinion and fit willingly in the homogenizing mold shaped by authorities.

Interestingly enough, the very diffusion of Stiliagy on television highlights the complex relations between the authorities and creative content. Authorities sought to limit representation of cultural patterns distant from the promoted ones. Stilyagi was released for the first time on television January $1^{\text {st }}, 2010$ to ensure that a mass audience would see it. However, the version shown on TV was censored and cuts were made to passages highlighting patterns of creativity that I previously laid out: the fabrication of homemade records on X-ray plates, one passage when one of the stilyagi's mother threatens to send Mels and his family to the gulag, and a scene of sexual intercourse between two unmarried protagonists, Mels and Polly. ${ }^{36}$ The censorship of Valery Todorovsky's film further underline how fiction resonates with reality and the possibility of a dialogue between Leto and Stilyagi on one side and Pussy Riot: A punk prayer on the other one. Stilyagi depicts the oppression of authoritarian regime against certain types of behaviors within the film. At once, the production is in itself subject to censorship because it mentions and represents certain actions and events deemed as intolerable by Putin's regime.

The boundaries of the "tolerable" are ever-shifting and are enforced by rulers through mobilization of the population. Indeed, as argued by Hannah Arendt, authorities make "promises of stability in order to hide their intention of creating a state of permanent instability." ${ }^{37}$ This is clearly visible in Putin's intervention at times of protests in Russia. The Russian leader regularly denounces "trouble-makers" posing a threat to the stability and security of Russia. Through such rhetoric discourses, Putin gained the support of the Russian population against the Pussy Riots. As shown in a poll conducted by the Levada Centre in 2013 only $6 \%$ of the respondents said they sympathized with the band ${ }^{38}$. Orthodox worshippers mobilized in front of the church to denounce the "blasphemous" actions of the three Pussy Riots activists.

36. KAGANOVSKY, 2014.

37. ARENDT, 1973.

38. Moscow Times, September 13, 2013. 
The animosity of the population toward subculture groups is similarly displayed in Stilyagi and Leto. In Stilyagi, Soviet "squares" employ the term "stilyagi" as an insult, as synonym for deviant, and they criticize "some people" that "do not want to live like everyone else." In Leto, a drunk man in a train shouts at the rockers for singing the "songs of the ideological enemy", the USA, and for refusing to fit into the Soviet mold. Soviet citizens encourage and conduct by themselves the repression against subculture groups that they consider abhorrent. The authorities spread narratives displaying stilyagi, rockers and feminist punk bands as a destabilizing force in society. In turn, citizens are led to support a strong leader that act to restore order. Authoritarian leaders manipulate and perpetuate this fear of instability to enforce their power.

The three productions permit to acknowledge key mechanisms of authoritarian regime against subculture. The relations between authorities and sub-culture movements are complex, fluid and interlinked. The latter does not necessary pose a direct threat to the former. Subculture's expressions can consist in parallel cultural practices and are not always directly opposed to authorities. Authoritarian regimes seek to control forms of expression that do not fit into the promoted way-of-life through various strategies. The maintenance of a constant instability leads citizens to self-censorship or to conduct by themselves repression against sub-culture groups.

\section{Conclusion}

Subculture groups, as they distinguish themselves from the masses, are seen as threats by authoritarian regimes. They are more or less tolerated by the authorities, but a constant sense of instability is created by authoritarian leaders seeking to maintain their power. Subculture groups must stand at once within and outside of society to be able to express themselves as they perform in creative behaviors, with their style, argot, rituals. They must not cross the moving-boundaries of acceptable norms set by the State or they risk facing violent repression. The production of films and the actions of the Pussy Riot underline the persistent value of heterogeneity in society. The production of films using the past to underline the persistent value of heterogeneity in society are reactions against the growing repression of Putin's regime. However, these creative outlets, by pushing the boundaries of freedom, can be used to change the very definitions of what constitutes that boundary. For instance, rappers were censored at the end of December 2018 for their lyrics mentioning drugs and using swear words. Yet the presenter Dmitri Kiseliov argued on State television at that time that rap was fundamentally Russian as it "originates 
SLOVO

306 Les Voyages lointains des écrivains polonais $\left(\mathrm{XX}^{\mathrm{e}}-\mathrm{XXI}^{\mathrm{e}}\right.$ siècles $)-\mathrm{n}^{\circ} 51$

from poetic tradition of the famous Soviet poet and writer, Vladimir Mayakovsky." 39 Moments as such show that the authorities themselves appropriate the past to shape the boundaries of creation.

\section{Bibliography}

Belikov Egor, «“Этого не бымо”: может ми Борис Гребенщиков критиковать “Аето” Киримла Серебренникова», Tass, 7 June, 2018.

Arendt Hannah, 1973, The Origins of Totalitarianism, Houghton Mifflin Harcourt, London/New York, 576 p.

Boym Svetlana, 2008, The Future of Nostalgia, Basic books, New York, 432 p.

Boym Svetlana, 1995, "From the Russian Soul to Post-Communist Nostalgia" in Representations, $\mathrm{n}^{\circ}$ 49, pp. 133-166.

Bryanski Gleb, September 12, 2012, "Russian Prime Minister Medvedev says Pussy Riot Should be Freed" in Reuters.

Davletgildeev Renat, April 19, 2018, «Этот фильм не вполне про Цоя». Сценаристы "Аета" Киримла Серебренникова о кино, снятом вопреки всему» in Current Times.

Kaganovsky Lilya, 2014, "Russian Rock on Soviet Bones" in Kaganovsky Lilya \& Salazkina Masha (eds.), Sound, Speech, Music in Soviet and Post-Soviet Cinema, Indiana University Press, Bloomington, pp. 252-272.

Kolesnokov Andrei, January 14 ${ }^{\text {th }}, 2019$, "Rapping for the Kremlin: The Regime Hijacks a Youth Subculture" in Carnegie Moscow Center.

Korzina Zina, February $4^{\text {th }}, 2009$, «Стиляги: как это было?» in Lady.mai.ru.

Larionova L., January 23, 2009, «O фильме «Стимяги» и не только» in Stavropolskaya Pravda,.

39. KolesNoKov, 2019. 
Laruelle M., 2009, In the Name of the Nation: Nationalism and Politics in Contemporary Russia, Springer, Berlin, $254 \mathrm{p}$.

Liñán M.V., 2010, "History as a Propaganda Tool in Putin's Russia” in Communist and Post-Communist Studies, n ${ }^{\circ}$ 43(2), pp. 167-178.

MacFarquhar Neil, Nov. 23, 2018, "Rapper Is Jailed for 12 Days in Russia as a Culture War Spreads" in New York Times.

Macheret Mathieu, 4 ${ }^{\text {th }}$ December 2018, « "Leto": par la grâce du rock, en Union soviétique », Le Monde.

Mijnssen I., 2014, The Quest for an Ideal Youth in Putin's Russia I: Back to Our Future! History, Modernity, and Patriotism according to Nashi, 2005-2013, Columbia University Press, New York, 268 p.

Moscow Times, September 13, 2013, "Russians Have No Respect for Pussy Riot, Poll Says".

Moscow Times, March 30, 2018, "Russia Bans Popular LGBT Website for 'Propaganda of Nontraditional Sexual Relations'”.

Nikolayenko O., 2008, "Contextual Effects on Historical Memory: Soviet Nostalgia Among post-Soviet Adolescents" in Communist and Post-Communist Studies, $\mathrm{n}^{\circ}$ 41(2), pp. 243-259.

Osborn Andrew , March 2, 2018, "Putin, Before Vote, Says He'd Reverse Soviet Collapse if he Could: Agencies" in Reuters.

Reagan Ronald, 1983, "Evil empire speech" in Voices of Democracy: The US Oratory Project.

The Hollywood Reporter, January 26 ${ }^{\text {th }}$, 2013, "Sundance 2013: Festival Awards Announced".

Throsby D., 2010, The Economics of Cultural Policy, Cambridge University Press, Cambridge, $294 \mathrm{p}$.

Wijermars M., 2018, Memory Politics in Contemporary Russia: Television, Cinema and the State, Routledge, London, $258 \mathrm{p}$. 
SLOVO

308 Les Voyages lointains des écrivains polonais $\left(\mathrm{Xx}^{\mathrm{e}}-\mathrm{XXI}^{\mathrm{e}}\right.$ siècles $)-\mathrm{n}^{\circ} 51$

Wilkinson Alissa, May 11, 2018, "Leto, Directed by an Outspoken Putin Critic, is a Tribute to the Soviet Underground Rock Scene" in Vox.

Williams J. Patrick, 2009, "The Multidimensionality of Resistance in YouthSubcultural Studies" in The Resistance Studies Magazine, n 1, pp. 20-33.

Williams J. Patrick, 2007, "Youth-subcultural studies: Sociological traditions and core concepts" in Sociology compass, $\mathrm{n}^{\circ} 1.2$, pp. 572-593.

YurchaK Alexei, 2013, Everything was Forever, Until it Was no More: The Last Soviet Generation. Princeton University Press, Princeton, 331 p. 